\title{
Physiotherapy Service Process On The Physical Development Of Children With Physical Disabilities At Yayasan Melati Anak Bangsa Martapura
}

\author{
Hanifa Nurunnisa, Imam Yuwono, Monry Fraick Nicky Gillian Ratumbuysang \\ Special Education Study Program, Faculty of Teacher Training and Education \\ University of Lambung Mangkurat \\ Banjarmasin, Indonesia \\ nhann_Soe@yahoo.com
}

\begin{abstract}
Physiotherapy can be intended as a treatment to reduce the adverse effects of physical obstacles experienced by children with physical disabilities. However, most people still do not know how to implement physiotherapy services for children with physical disabilities. In accordance with these problems, this study aims to provide a descriptive description of the physiotherapy service process on the physical development of physical children with physical disabilities at Yayasan Melati Anak Bangsa (YMAB) Martapura. This study employed a descriptive research with a qualitative approach. The subjects were physiotherapists, children with physical disabilities, and parents of the children with special needs at YMAB. The data was collected using triangulation methods in the form of interviews, observation, and documentation. The research instruments used were in the form of interviews, observation guidelines and documentation guidelines. Data analysis techniques used were data reduction, data display and conclusion drawing. The results showed that the process of physiotherapy service on the children with physical disabilities at Melati Anak Bangsa YMAB consisted of: (1) Assessment, in the form of amnesis which became the basis of information about the patient's physical/health condition, (2) Diagnosis, performed carefully through clinical studies conducted by physiotherapists and teams, (3) Intervention Planning, tailored to the needs of patients and formulated by referring to the results of clinical examinations and assessment studies and previous diagnoses, (4) Interventions, carried out using techniques/methods and physiotherapy aids according to the needs of patients by prioritizing the safety, comfort and safety of patients, (5) Evaluation, carried out when there was a change in the health status of patients that is increasing or decreasing, (6) Communication and Education, aimed at parents/families of patients regarding information on physiotherapy services that could be carried out independently, and (7) Documentation, summarized in the patient's medical record. Based on these findings, it is suggested that the foundation holds physiotherapy facilities in the form of physiotherapy aids that have not been owned. In addition, it is suggested to the Special Education Study Program, University of Lambung Mangkurat, to hold physiotherapy services in the therapeutic laboratory.
\end{abstract}

Keywords-physiotherapy service; physiotherapists; children with physical disabilities.

\section{INTRODUCTION}

Children with physical disabilities are one of the scopes in the field of children with special needs (ABK). Children with physical disabilities is a term for children who experience physical disorders, both physical disorders that are innate and those caused by external factors involved in daily life. At the same time, the form of this body dysfunction in children with physical disabilities can vary. It could be caused by neurological, muscular, joint or post-accident paralysis, which has an impact on aspects of services provided to the children with physical disabilities. The services are education or health services related to the recovery aspects of physical function [13].

Based on observation, it was found that there is a foundation offering health services for children with special needs. This foundation is Yayasan Melati Anak Bangsa (YMAB). In this foundation, the researchers found a method of therapy by using physiotherapy as an alternative treatment for children with special needs with the help of professionals YMAB itself is a foundation located in Martapura, Banjar Regency, South Kalimantan. This foundation is a non-profit foundation providing services to children with special needs by issuing health services with the help of experts and professionals such as doctors to fill health checks for children with special needs, nutritionists for nutrition consultation for children with special needs, psychologists to provide consultation services for children and families, and physiotherapists who handle physiotherapy services for children with physical disabilities.

The existence of health services at the YMAB can be a solution for parents and children with special needs for health services by professionals. However, its existence and general information of the health services at this foundation is still not widely known by the public, particularly regarding the physiotherapy services offered by this foundation as a treatment aimed at children with special needs. Lack of information in the middle of the community abou physiotherapy services that can be intended as a treatment for children with special needs causes public ignorance about the physiotherapy services. In accordance with this problem, this 
study aims to provide a description of "physiotherapy service process on the physical development of children with physical disabilities".

\section{METHOD}

This study is a descriptive study using a qualitative approach. The research subjects were determined by a purposive sampling technique. There were six participants involved in this study namely two physiotherapists, two children with physical disabilities, and two parents of children with physical disabilities. The data collection were carried out through observation, interviews, and documentation. Meanwhile, the data analysis was conducted by data reduction, data presentation, conclusion drawing as well as data validity techniques using triangulation [4],[5].

\section{RESULT AND DISCUSSION}

Assessment stage in the process of physiotherapy services for children with physical disabilities Yayasan Melati Anak Bangsa was in the form of amnesis (interview). Amnesis in the patient itself includes general information about the patient such as name, age, gender, address, name of parents to more specific information in the form of the patient's disease history, birth history, medical history, and any other relevant information. This is in accordance with reference [6] that includes general identity, systemic review, complaint history, and examination (test and measurement). The results of this amnesis can be seen in the medical records of patients found at YMAB. The assessment phase in physiotherapy services then became the basis of information for the next stage, namely the diagnostic phase.

The diagnosis given at YMAB aims to provide an overview of the condition or physical/ health condition of the patient for the benefit of the physiotherapy services that will be given to the patient. The diagnosis given to patients with physical disabilities at YMAB was the result of clinical studies conducted by physiotherapists and teams. This study included the physical/ health examination of patients and the assessment of previous assessment results. In accordance with reference [7], physiotherapy diagnosis is the result of a clinical study process that results in the identification of a disturbance or potential for interference, limited function, and disability. The purpose of diagnosis directs the physiotherapist to determine the most appropriate prognosis and intervention strategy for the patient and to provide information. In the physiotherapy diagnosis process at YMAB, there was a first examination stage carried out by the physiotherapist and team consisting of physiotherapists and doctors. This examination was in the form of checking physical conditions and reviewing the results of the previous assessments. The results of the diagnosis then became a reference for the next stage in the physiotherapy service process YMAB namely the intervention planning stage.

The planning stage of this intervention was carried out by the physiotherapist before intervening the patient. Physiotherapists planned physiotherapy interventions based on the results of previous assessments and diagnoses in which planning of this intervention would be informed or communicated to the parents, family, and patients themselves.
In accordance with reference [5], respecting the rights of patients and families to obtain all information related to physiotherapy services provided, including information on physiotherapy service sources that can be easily accessed by patients if they need advanced physiotherapy services. Furthermore, the intervention plan that had been informed in advance to the patient and parents/family would be followed up in the intervention stage [8-10].

Intervention stage was carried out based on previous intervention planning programs. Field observations showed that the intervention process provided to patients was carried out with extreme caution, taking into account the safety and comfort of patients when given intervention. This is in accordance with the reference [6] that the quality and safety of patients must always be embedded in every physiotherapy service activity, both in the clinical care process and in the managerial process, which is understood by all staff/members. The intervention provided by the physiotherapist to the patient was carried out with caution without prejudice to the techniques and methods of intervention for patients who have been planned in advance. The intervention carried out in physiotherapy services at YMAB was in accordance with the intervention plan that had been formulated previously, including both physiotherapy techniques and assistive devices to be used for patients. In addition, physiotherapy services at the intervention stage also took into account the comfort and safety of the patient in question, so that the physiotherapy services provided to patients were qualified physiotherapy services. Providing interventions that prioritized patient safety and comfort in the physiotherapy service process at YMAB is in accordance with the reference [6], namely providing physiotherapy services to individuals, families, groups, and communities. It also solves functional problems and needs of the functional motion of the human body by applying physiotherapy technology safely, qualitatively, effectively and efficiently with a holistic holistic approach, guided by a code of ethics, evidence-based, referring to standards/guidelines, and it can be accounted for.

Then, the physiotherapy evaluations found at YMAB were carried out clearly and thoroughly by the physiotherapist. In accordance with the reference [7] that physiotherapists in carrying out physiotherapy practices are authorized to do: physiotherapy assessment, physiotherapy diagnosis, physiotherapy planning, physiotherapy intervention, and evaluation/re-evaluation/re-assessment. Therefore, in this case, the physiotherapy evaluation at YMAB carried out by the physiotherapists was based on their authority. Evaluations conducted by physiotherapists at YMAB were not only limited to changes in patients who experience an increase in health status or an increase in physical function, but also on patients who experience a decline in health status. The researchers assess this as the right action considering each patient different conditions and does not rule out the possibility of a decrease in the level of health in the patient concerned, so that evaluation becomes an important thing that must be done in order to become a reference material for the formulation of further interventions and reference material to other experts like doctors. Evaluation can be in the form of conclusions, 
advanced planning interventions, or referrals to doctors or other relevant professionals.

Then, the next stage was communication and education stage as a part of the physiotherapy service process. This stage was carried out by the physiotherapist and the team to parents, family, and clients. Communication and education phase were carried out in two directions between the physiotherapist and parents/family. Communication and education wee given to patients' parents were about the physiotherapy service itself. The researchers found out that two-way communication carried out in the process of physiotherapy was very efficient for the benefit of physiotherapy services, the purpose of communication to patients or parents themselves was to provide information related to physiotherapy care. In this case, the communication is the right medium to provide education related to the implementation of physiotherapy independently for parents/families of patients [8-12].

Physiotherapy documentation was also enforced in the physiotherapy service process at YMAB. It was included in physiotherapy medical record sheets. Physiotherapy documentation is important so that patient data is structured in sheets called medical records in order to improve health services at YMAB. The medical record is a sheet containing patient data concerning actions based on authority and responsibility as medical personnel in achieving health service goals. Physiotherapy medical partners found at YMAB consists of patient's data, amnese results in the form of disease history, physical examination, functional/motor skills, diagnosis results, and physiotherapy actions and evaluations given from the beginning of intervention until the end of physiotherapy intervention to patients. This is in accordance with reference [7], that physiotherapy records are started since the patient is at the physiotherapy service facility, until the end of the service period. It aims that the stages of documentation of physiotherapy at YMAB are in accordance with the procedures set out in the Regulation of the Minister of Health.

\section{CONCLUSION}

Based on the description of the physiotherapy service process on the physical development of children with physical dissabilities at Yayasan Melati Anak Bangsa (YMAB), Martapura, it can be concluded that the physiotherapy service process provided at YMAB consists of: (1) Patient Assessment, in the form of amnesis which forms the basis of information on physical conditions/health of patients with physical impairment for the benefit of physiotherapy services, (2) Diagnosis, carried out very carefully through clinical studies conducted by physiotherapists and teams, (3) Intervention Planning, tailored to the needs of the patient concerned and formulated by referring to clinical examination results as well as assessment and diagnosis studies, (4) Interventions, carried out carefully and professionally using physiotherapy techniques and methods according to the needs of patients by prioritizing patient safety, comfort and safety, (5) Evaluation, which is done when changes are seen on the health degree in patients, and to not only limited to changes in the degree of health improvement, but also enforced in patients who experience a decline in health status, (6) Communication and Education, intended for parents/families of patients to provide information and education related to physiotherapy services that can be done independently, (7) Documentation, summarized in full in medical records of patients with disabilities. The process of physiotherapy services found at Yayasan Melati Anak Bangsa is in accordance with the applicable procedures in the Minister of Health Regulation No. 65 of 2015 concerning Standard Physiotherapy Services.

\section{REFERENCES}

[1] A. Karyana, and A. A Sarip Hidayat, Bina Gerak Bagi Anak Berkebutuhan Khusus Tunadaksa. Jakarta Timur: PT Luxima Metro Media, 2013.

[2] A. Karyana, and S. Widati, Pendidikan Berkebutuhan Khusus Anak Tunadaksa. Jakarta Timur: PT Luxima Metro Media, 2013.

[3] A. Murti, Ensiklopedi Anak Berkebutuhan Khusus. Jogjakarta: Redaksi Maksima, 2014

[4] Sugiyono, Metode Penelitian Kualitatif. Bandung: Alfabeta, 2016.

[5] M. D. Ghony and F. Almanshur, Metode Penelitian Kualitatif. Yogyakarta: Ar-ruzz Media, 2014.

[6] Republik Indonesia, Peraturan Menteri Kesehatan Republik Indonesia Tentang Standar Pelayanan Fisioterapi Nomor 65 Tahun 2015. Jakarta: MENKES, 2015.

[7] Republik Indonesia, Keputusan Menteri Kesehatan RI Nomor: 778/MENKES/SK/VIII/2008 tentang Pedoman Pelayanan Fisioterapi di Sarana Kesehatan. Jakarta: MENKES, 2008.

[8] E. Bajraszewski, R. Carne, R. Kennedy, A. Lanigan, K. Ong, M. Randall, D. Reddihough, and B. Touzel, Cerebral Palsy An Information Guide For Parents, 2nd ed. Melbourne: Royal Children's Hospital, 2000.

[9] S. Sudarsini, Fisioterapi. Malang : Gunung Samudera, 2017.

[10] K. W. Hayes, and K. D. Hall, Agens Modalitas Untuk Praktik Fisioterapi. Jakarta: Penerbit Buku Kedokteran EGC, 2016.

[11] D. Desmita, Psikologi Perkembangan Peserta Didik. Bandung: PT Remaja Rosdakarya, 2014.

[12] S. Yusuf, and N. M. Sugandhi, Perkembangan Peserta Didik. Jakarta: PT RadjaGrafindo Persada, 2011. 